\title{
STUDY OF HEPATOPROTECTIVE ACTIVITY OF STINGLESS BEE PROPOLIS AGAINTS TOXICITY OF DRUGS
}

\author{
MAHANI ${ }^{1,2 *}$, GREGORIUS A O B ${ }^{1}$, ENDAH WULANDARI ${ }^{1}$, AHMAD SULAEMAN ${ }^{2}$, HARDINSYAH ${ }^{2}$, \\ NUNUNG NURJANAH ${ }^{3}$
}

${ }^{1}$ Department of Food Technology, Faculty of Agric. Industrial Technology, Universitas Padjadjaran, Indonesia. ${ }^{2}$ Department of Community Nutrition, Faculty of Human Ecology, IPB University, Indonesia. ${ }^{3}$ National Institute of Health Research and Development, Indonesian Ministry of Health Indonesia. Email: mahani2018@unpad.ac.id

Received: 23 September 2021, Revised and Accepted: 10 November 2021

ABSTRACT

Objective: The aim of this study is to determine the effect of stingless bee propolis supplementation as a hepatoprotector on the prevention of Druginduced liver injury (DILI) and the effect of healing and restoring nutrition for DILI patients due to drug induction.

Methods: The literature review starts from problem identification, library data collection, reading, taking notes, analyzing, and processing the data obtained and then compiling it into a systematic review.

Results: The results of a literature study conducted show that propolis has a good hepatoprotective ability against drugs that cause DILI cases such as the anti-tuberculosis, antibiotic, and antipyretic groups as indicated by the serum glutamic pyruvic transferase, serum glutamic oxaloacetic transferase, total bilirubin, glutathione, and superoxide dismutase values that are close to normal values. In addition, propolis supplementation can accelerate the healing and restoration of the nutritional status of DILI patients. All active compounds contained in propolis such as phytochemicals and lipopolysaccharides work to protect the liver from the toxic effects of DILI through antioxidant mechanisms.

Conclusion: Overall, the data from this literature study show that the hepatoprotective activity of propolis has the potential to complement drug therapy to reduce hepatotoxic effects and can conclusively beneficial to accelerate the restoration of nutritional status for DILI patients.

Keywords: Antioxidant, Drug-induced liver injury, Hepatotoxic Hepatoprotective, Propolis.

(C) 2021 The Authors. Published by Innovare Academic Sciences Pvt Ltd. This is an open access article under the CC BY license (http://creativecommons.org/ licenses/by/4.0/) DOI: http://dx.doi.org/10.22159/ajpcr.2021v14i12.43217. Journal homepage: https://innovareacademics.in/journals/index.php/ajpcr

\section{INTRODUCTION}

Drug-induced liver injury (DILI) is a diagnosis in patients who have liver damage caused by consuming drugs that are liver damage or hepatotoxic [1]. DILI can be caused by drugs that are hepatotoxic including anti-tubercular drugs (Rifampicin, Isoniazid, and Pyrazinamide) [2-4], nonsteroidal anti-inflammatory drugs (Ibufenac, Acetaminophen) [5], anti-retroviral drugs (Ritonavir and Indinavir) [6], anti-hyperlipidemic drugs (Statins, Atorvastatin) [7,8], anesthetic agents (CCl4, Chloroform) [9], and antibiotics (tetracycline and monocycline) [10].

The DILI study found that antibiotic, antibacterial, and anti-tuberculosis drugs were drugs with high hepatotoxic effects compared to other drugs. Based on the diagnostic criteria for hepatotoxicity and the population studied, the reported incidence of anti-TB hepatotoxicity increased from $2 \%$ to $28 \%$ [11]. The study by the US DILIN cohort reported $46 \%$ cases of anti-TB hepatoxicity [10]. In India, cases of anti-TB hepatotoxicity were reported in 58\% and cases of death due to hepatotoxicity of anti-TB drugs reached 9.5\% [12]. For this reason, the WHO strongly encourages research with the main aim of finding new drugs to tackle drugs that are more effective and with the lower side effects than existing drugs [13]. At present, supplements derived from natural products, fruits, vegetables, herbs, and spices have many biological properties and have the potential to fight several diseases [14]. One that is starting to be developed a lot is propolis which has many pharmacological effects.

Propolis is a resin collected by bees from various plants, which mixes with saliva and various enzymes to produce a new, different resin. Propolis has antibacterial, anti-inflammatory, antiviral and other biological activities such as anti-inflammatory, local anesthetics, hepatoprotections, anti-tumor, and immunostimulants [15]. Animal studies have shown that propolis has an antimicrobial effect $[16,17]$, antiviral [18,19], antifungals [20,21], anti-parasitic [22,23], antiinflammatory [22], and anti-tumor [24]. Propolis contains antioxidants and has anti-inflammatory, immunoregulatory, bacteriostatic and bactericidal effects [22,25]. Bhadauria et al. [26] suggested that propolis has the potential as a hepatoprotector in chronic liver injury by maintaining its antioxidant activity.

\section{METHODS}

The literature review starts from problem identification, library data collection, reading, taking notes, analyzing, and processing the data obtained and then compiling it into a systematic review. The method is generally divided into two stages; The first stage is the stage related to the data collected, consisting of: Problem identification, determining library sources based on eligibility criteria and inclusion or exclusion criteria, data collection, and sorting based on the suitability of the literature with the topics discussed. The second stage is processing the data that have passed the sorting, consisting of: Data analysis and interpretation and confirmation. Data that have been confirmed will be included in the review, while unconfirmed data will be re-sorted.

\section{RESULTS AND DISCUSSION}

Hepatoprotective activity of propolis

Hepatoprotectors are compounds or substances that can protect cells as well as repair damaged liver tissue due to toxic substances [27]. Free radical damage in the body can be overcome with antioxidants. Antioxidant is defined as a substance that can delay, prevent, or eliminate 
oxidative damage to target molecules, for example, proteins, lipids, and DNA [28]. Giving hepatoprotectors can be done for prevention or healing (curative) [29]. Table 1 summarizes the literature data searched concerning hepatoprotective activity of propolis.

Studies of propolis as a hepatoprotector in vivo with the induction of hepatotoxic DILI drugs have been carried out by several researchers using analytical methods such as the Kruskal-Wallis test, the MannWhitney Advanced Test, the ANOVA test, the Tukey HSD Advanced Test, and the post hoc test. In general, hepatoprotective compounds have high antioxidant activity [30]. High antioxidant activity will prevent fat peroxidation and tissue damage in the liver caused by the presence of incoming free radical compounds such as hydroxyl radicals, superoxide anions, and nitric oxide [28].

Research conducted by Mahani et al. [31] analyzed several propolis obtained from regions throughout Indonesia. The propolis chosen as the best candidate as a complementary hepatoprotector for ATD is the propolis Geniotrigona incisa from South Sulawesi province. This propolis has very high antioxidant activity to reduce hepatotoxic effects ( IC $_{50} 100.05 \mathrm{ppm}$ ), low toxicity (854.75 ppm), and strong M.Tbc inhibition (49.84\%).

The hepatoprotective effect of propolis with high antioxidant activity was also found to protect the liver from the toxic effects of taking the drug atorvastatin according to Abdelsameea et al. [32]. The study using Egypt Native propolis was carried out on 56 albino mice divided into seven groups; Group I (25 mg/kg propolis in $1 \mathrm{ml}$ distilled water), Group II (25 mg/kg atorvastatin in $1 \mathrm{ml}$ distilled water), Group III (50 mg/kg propolis in $1 \mathrm{ml}$ suspension $+20 \mathrm{mg} / \mathrm{kg}$ atorvastatin in $1 \mathrm{ml}$ distilled water), Group IV (100 mg/kg propolis $+20 \mathrm{mg} / \mathrm{kg}$ atorvastatin in $1 \mathrm{ml}$ distilled water), Group V ( $80 \mathrm{mg} / \mathrm{kg}$ atorvastatin in $1 \mathrm{ml}$ distilled water), Group VI (50 mg/kg propolis in $1 \mathrm{ml}$ suspension $+80 \mathrm{mg} / \mathrm{kg}$ atorvastatin in $1 \mathrm{ml}$ distilled water), and Group VII (100 mg/kg propolis in $1 \mathrm{ml}$ suspension $+80 \mathrm{mg} / \mathrm{kg}$ atorvastatin in $1 \mathrm{ml}$ distilled water).

After 1 month, hepatocyte degradation was obtained at a dose of $20 \mathrm{mg} / \mathrm{kg}$ and $80 \mathrm{mg} / \mathrm{kg}$ of Atorvastatin. Atorvastatin can cause acute hepatotoxicity, especially in women aged over 60 years [33]. The group treated with the addition of $50 \mathrm{mg} / \mathrm{kg}$ and $100 \mathrm{mg} / \mathrm{kg}$ of propolis showed a significant decrease in serum alanine aminotransferase (ALT), aspartate aminotransferase (AST) levels and catalase enzyme activity (CAT), and superoxide dismutase (SOD) as biomarkers of hepatocyte degradation. The addition of propolis treatment can protect the liver from oxidative stress that occurs due to Atorvastatin administration. Banskota et al. [34] stated that the hepatoprotective effect of propolis can help reduce D-galactosamines which trigger tumor necrosis in rat hepatocytes. Omar et al. [35] added that Egypt Native propolis has been shown to have a hepatoprotective effect against the anticancer agent Doxorubicin which causes side effects such as cardiotoxicity, hepatotoxicity, and nephrotoxicity in mice. Polyphenol compounds that act as antioxidants can protect liver tissue damage from oxidative stress caused by consuming drugs.

Table 1: Hepatoprotection activity of propolis

\begin{tabular}{|c|c|c|c|c|c|}
\hline Propolis & Assay Method & Inductions & Analysis method & Biomarker compounds & Reference \\
\hline $\begin{array}{l}\text { Propolis extract } \\
\text { Geniotrigona } \\
\text { incisa }\end{array}$ & $\begin{array}{l}\text { Clinical assay } \\
\text { (TB patient) }\end{array}$ & $\begin{array}{l}\text { ATD (Rifampicin, Isoniazid, } \\
\text { Pirazinamid, Etambutol) }\end{array}$ & $\begin{array}{l}\text { Kruskal Wallis Test } \\
\text { and Mann Whitney } \\
\text { Advanced Test }\end{array}$ & SGPT, SGOT, BT, GSH, SOD & $\begin{array}{l}\text { (Mahani et al., } \\
\text { 2018) }\end{array}$ \\
\hline $\begin{array}{l}\text { Propolis ethanol } \\
\text { extract Trigona } \\
\text { sp. }\end{array}$ & $\begin{array}{l}\text { In vivo assay } \\
\text { (Wistar strain } \\
\text { male white rat) }\end{array}$ & Chlorampenicol & $\begin{array}{l}\text { ANOVA and Tukey HSD } \\
\text { Advanced Test }\end{array}$ & SGOT, ALP & (Mahdi et al., 2018) \\
\hline $\begin{array}{l}\text { Malaysian } \\
\text { propolis extract } \\
\text { Heterotrigona } \\
\text { itama }\end{array}$ & $\begin{array}{l}\text { In vivo assay } \\
\text { (Sprague-Dawley } \\
\text { strain adult male } \\
\text { rat) }\end{array}$ & Streptozotosin (STZ) & $\begin{array}{l}\text { ANOVA and Tukey HSD } \\
\text { Advanced Test }\end{array}$ & AST, ALT, ALP, GGT, BT & (Nna et al., 2018) \\
\hline $\begin{array}{l}\text { Propolis } \\
\text { hydroalkoholic } \\
\text { extract } \\
\text { Scaptotrigona aff. }\end{array}$ & $\begin{array}{l}\text { In vivo assay } \\
\text { (Swiss strain } \\
\text { male and female } \\
\text { rats) }\end{array}$ & No induction & $\begin{array}{l}\text { ANOVA and Tukey HSD } \\
\text { Advanced Test }\end{array}$ & AST, ALT, TC, TG & (Araujo et al., 2011) \\
\hline $\begin{array}{l}\text { Propolis ethanol } \\
\text { extract and } \\
\text { nanopropolis } \\
\text { Trigona spp. }\end{array}$ & $\begin{array}{l}\text { In vivo } \\
\text { (Sprague-Dawley } \\
\text { strain female rat) }\end{array}$ & $\begin{array}{l}\text { 7,12-Dimethylbenzaanthracene } \\
\text { (DMBA) }\end{array}$ & Kruskal Wallis Test & $\begin{array}{l}\text { Macroscopic observation } \\
\text { and histopathological } \\
\text { assessment }\end{array}$ & (Hasan et al., 2014) \\
\hline $\begin{array}{l}\text { Ekstrak etil asetat } \\
\text { propolis Apis } \\
\text { mellifera. }\end{array}$ & $\begin{array}{l}\text { Uji in vivo (pada } \\
\text { tikus galur } \\
\text { Wistar) }\end{array}$ & Epirubicin (antibiotik) & Uji ANOVA & (AST, ALT, SOD, CAT, GSH) & (Chaa et al., 2019) \\
\hline $\begin{array}{l}\text { Egypt Native } \\
\text { Propolis }\end{array}$ & $\begin{array}{l}\text { In vivo assay } \\
\text { (albino male and } \\
\text { female rats) }\end{array}$ & Atorvastatin & $\begin{array}{l}\text { ANOVA and Post-hoc } \\
\text { Test }\end{array}$ & AST, ALT, SOD, CAT & $\begin{array}{l}\text { (Abdelsameean } \\
\text { et al., 2013) }\end{array}$ \\
\hline $\begin{array}{l}\text { Egypt native } \\
\text { Propolis ethanol } \\
\text { extract }\end{array}$ & $\begin{array}{l}\text { In vivo assay } \\
\text { (Sprague-Dawley } \\
\text { strain adult male } \\
\text { rat) }\end{array}$ & Doxorubicin & ANOVA Test & $\begin{array}{l}\text { AST, ALT, Albumin, TP } \\
\text { and Histopathological } \\
\text { observation }\end{array}$ & (Ayoub et al., 2016) \\
\hline $\begin{array}{l}\text { European } \\
\text { propolis ethanol } \\
\text { extract }\end{array}$ & $\begin{array}{l}\text { In vivo assay } \\
\text { (Wistar-albino } \\
\text { strain male and } \\
\text { female rat) }\end{array}$ & Acetaminophen & ANOVA Test & (AST, ALT, ALP) & $\begin{array}{l}\text { (Ambardekar et al., } \\
\text { 2012) }\end{array}$ \\
\hline $\begin{array}{l}\text { Egypt Native } \\
\text { Propolis aqueous } \\
\text { extract }\end{array}$ & $\begin{array}{l}\text { In vivo assay } \\
\text { (Swiss Albino } \\
\text { strain male rat) }\end{array}$ & Octylphenol & ANOVA Test & AST, ALT, BT, SOD, GAT & (Saleh, 2012) \\
\hline
\end{tabular}




\section{EFFECT OF PROPOLIS ON DRUG TOXICITY IN LIVER}

Based on the literature studies, the drugs with the most potential in DILI and still widely used are the Anti-Tuberculosis (ATD) types Rifampicyn and Isoniazid which have hepatotoxicity side effects. Some researchers have found new types of OAT that have a lower hepatotoxicity effect such as quinolone drugs (moxifloxacin and levofloxacin). However, these drugs cause resistance and are quite expensive. Isoniazid itself can produce acetyl hydrazine and hydrazine by $\mathrm{N}$-asetyl transferase and amide hydrolysis enzymes which are toxic metabolites and a strong liver inducer [36]. Consumption of isoniazid together with rifampicin will cause rifampicyn toxicity to the liver, and significantly reduce the survival rate of liver cells [31]. The hepatotoxicity of rifampicyn increases sharply when combined with isoniazid, which is characterized by an increase in acetylhydrazine and hydrazine. Both are toxic metabolites. The mechanism of rifampicyn hepatotoxicity is mediated by oxidative damage [37] while rifampicyn hepatotoxicity through increased ALT concentration and other disorders causes the accumulation of bilirubin [3].

Anti-tuberculosis drugs are known to be hepatotoxic which is characterized by an increase in the concentration of serum glutamic

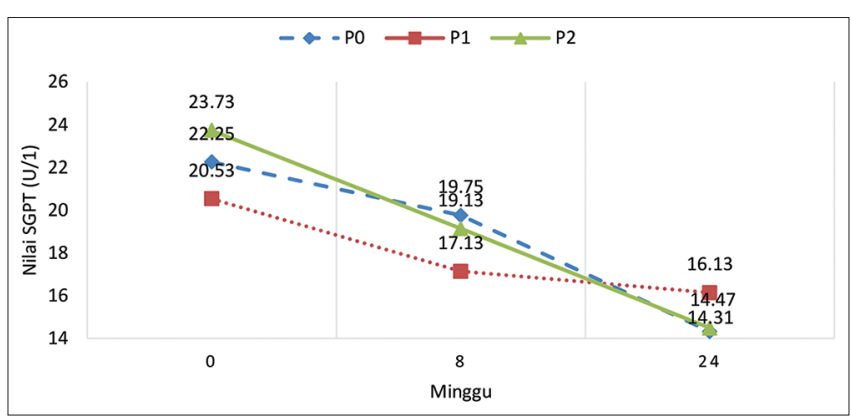

Fig. 1: Average change of the serum glutamic pyruvic transferase concentration Group P0 (ATD + Propolis placebo), P1 (ATD + Propolis 6\%) and P2 (ATD + Propolis 30\%) (Mahani et al., 2018)

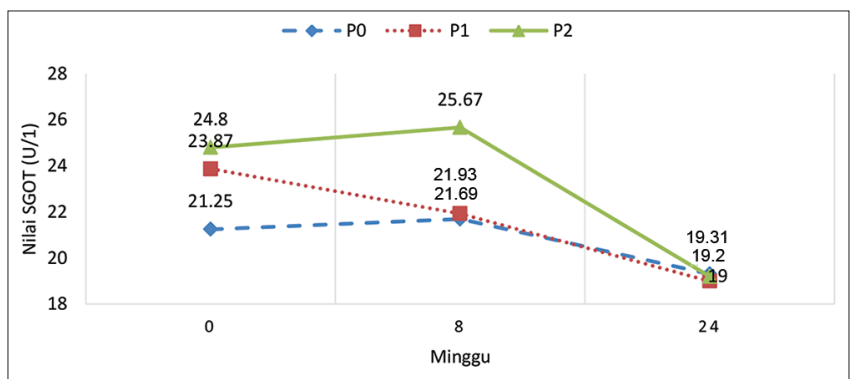

Fig. 2: Average change of the serum glutamic oxaloacetic transferase concentration Group PO (ATD + Propolis placebo),

P1 (ATD + Propolis 6\%), and P2 (ATD + Propolis 30\%) (Mahani et al., 2018)

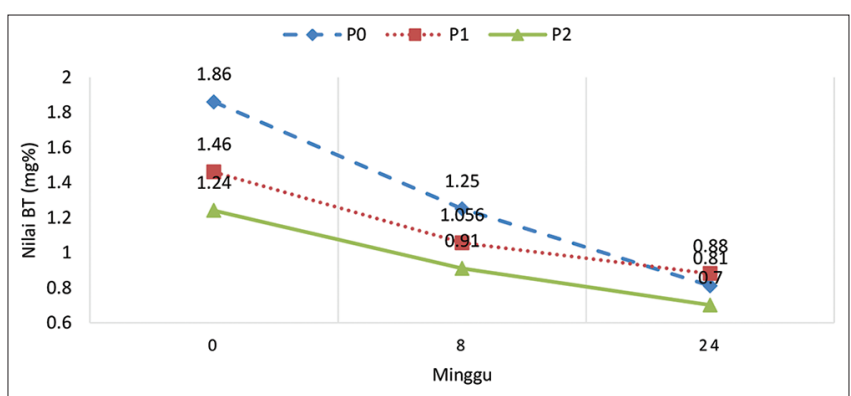

Fig. 3: Average change of total bilirubin concentration in Group P0 (ATD + Propolis placebo), P1 (ATD + Propolis 6\%), and P2 (ATD + Propolis 30\%) pyruvic transferase (SGPT) biomarkers, serum glutamic oxaloacetic transferase (SGOT), total bilirubin (BT), ALP and decreased concentrations of SOD, Glutathione (GSH), glutathione peroxidase (GPX), and CAT [38]. Clinically the symptoms of ATD toxicity are decreased appetite, decreased body weight (BW), insomnia, skin rash, nausea/vomiting, diarrhea, epigastric pain, fatigue, dizziness/headache, fever, peripheral neuropathy, and dysmenorrhea [39,40]. Free radical activity in TB patients who consumed ATD was very high and had low antioxidant status. This occurs because the oxidative stress mechanism to fight M.tbc infection causes depletion of antioxidants. Propolis has been widely researched and is able to provide hepatoprotective effects both in vitro, in vivo, and clinically. Research conducted by Bhadauria et al. [41], Hashmi et al. [42], Cevik et al. [43], and Omar et al. [35] showed that propolis is an antioxidant and can protect the liver from the toxic effects of drugs and ATD. The effectiveness of propolis in protecting the liver from the hepatotoxicity effects of AOT can be seen from its biomarkers, namely, SGPT, SGOT, BT, GSH, and SOD.

\section{EFFECT OF PROPOLIS ON SGPT LEVEL}

Effect of propolis on SGPT level has described by Mahani et al. [31] clinically in three groups, Group P0 (ATD + propolis placebo), P1 (ATD + propolis 6\%), and P2 (ATD + propolis 30\%). During the intervention, Group P2 experienced the greatest decrease in SGPT and conversely, Group P0 experienced the smallest decrease in SGPT. This shows that the greater the concentration of propolis supplementation, the greater the ability to reduce liver toxicity.

These results are in line with the study conducted by Tanvir et al. [44]. SGPT concentrations in the treatment with Tetracycline (TTC) and Bangladeshi propolis were found to be significantly lower when compared to the TTC treatment in rats. TTC is toxic to the liver and can cause necrosis of hepatocytes and an inflammatory reaction $[45,46]$. Provision of propolis can maintain the integrity of the membrane and inhibits the leakage of enzymes in the blood. This protective mechanism is related to the presence of phenolic compounds (gallic acid, benzoic acid, salicylic acid, pyrogallol, and routine), tannins, ascorbic acid,

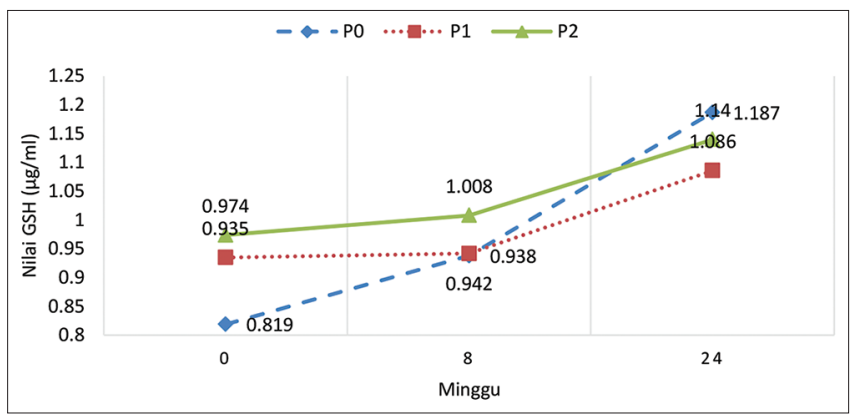

Fig. 4: Average change of the Glutathione concentration in Group P0 (ATD + Propolis placebo), P1 (ATD + Propolis 6\%), and P2 (ATD + Propolis 30\%)

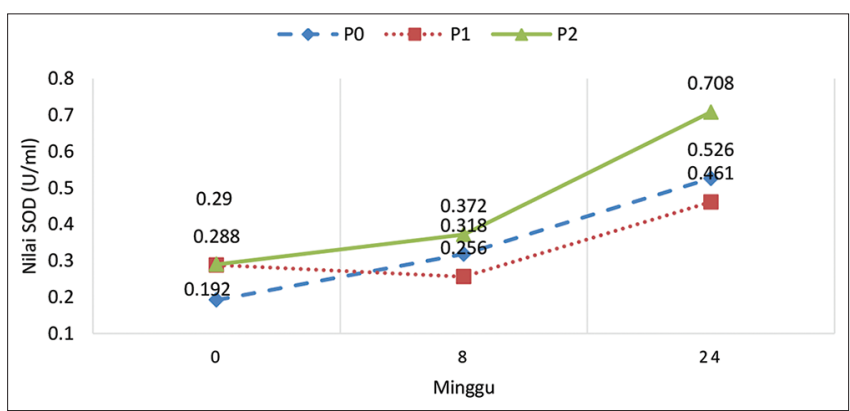

Fig. 5: Average change of the superoxide dismutase concentration in Group P0 (ATD + Propolis placebo), P1 (ATD + Propolis 6\%), and P2 (ATD + Propolis 30\%) 
and Vitamin E in propolis extract which have inhibitory activity on membrane fat peroxidation with strong antioxidant activity [47-49].

These results are also supported by the research of Saleh [50] which states that aqueous extract of propolis can reduce the damage and hepatotoxicity effects on liver cells induced by 4-tertiary-octylphenol (4-tert-OP). ALT levels in mice given 4-tert-OP induction showed a significant increase when compared to controls, while mice given propolis extract had lower ALT levels than controls. In this case, propolis is believed to help repair liver damage caused by 4-tertOP. The flavonoid compounds in propolis have been shown to have a hepatoprotective effect by binding to heavy metal ions thereby suppressing the formation of free radicals.

\section{EFFECT OF PROPOLIS ON SGOT LEVEL}

Besides SGPT, Mahani et al. [31] also measured the concentration of SGOT in three groups. The SGOT concentrations in the $\mathrm{P} 0$ and $\mathrm{P} 2$ groups experienced a surge in the eighth week, increasing 0.44 and $0.87 \mathrm{U} / \mathrm{l}$, respectively. This is in contrast to the previous SGPT concentration. In the P1 group, it actually experienced a decrease of $1.93 \mathrm{U} / \mathrm{l}$. SGOT, like SGPT, is indispensable in medicine because it acts as a protein metabolite transporter [30]. The increase in SGOT is the body's homeostasis mechanism to carry out the optimal biotransformation of metabolites for treatment. ATD consumption will produce large amounts of ATD radical metabolites. This metabolite is needed to kill M.tbc. one of the ATDs that are often used and known to be very toxic is isoniazid. The compounds in these drugs are considered foreign by the body, so they are converted by the liver into metabolites, namely, hydrazine, acetyl hydrazine and monoacetyl hydrazine. These metabolites are more soluble and can be accepted by the body, but are radical and toxic $[37,51]$. This radical nature will kill M.tbc. The transformation of drug compounds into various metabolite compounds is carried out by transporter proteins, namely, SGPT and SGOT.

This is in line with the research of Mahdi et al. [30] that showed the provision of Trigona sp. can reduce SGOT and ALP levels significantly in Chloramphenicol-induced rats. Chloramphenicol in large doses will damage liver cells and increase SGOT and SGPT levels. According to Saba et al. [52], Chloramphenicol has been shown to have a hepatotoxic effect, causing elevated levels of liver enzymes in the blood. This study was conducted in five groups; negative control, positive control $(400 \mathrm{mg} / \mathrm{kgBW}$ Chloramphenicol), Group I (400 mg/kgBW Chloramphenicol + $8 \mathrm{mg}$ propolis), Group II (400 mg/kgBW Chloramphenicol $+16 \mathrm{mg}$ propolis), and Group III (400 mg/kgBW Chloramphenicol + $24 \mathrm{mg}$ propolis). In the negative control, the SGOT concentration was in the normal range. This is because the body is able to balance the number of free radicals and antioxidants. The highest SGOT concentration was found in positive control. This is due to increased oxidative stress in the body due to Chloramphenicol.

Another study conducted by Ambardekar et al. [53] using propolis liposomes in mice induced by acetaminophen or better known as paracetamol. The liver damage in mice in this study was caused by the toxic metabolite $\mathrm{N}$-acetyl-p-benzoquinone imine (NAPQI) which is produced as a result of biotransformation using the enzyme cytochrome P450 as a catalyst. Under normal conditions, this metabolite is detoxified by GSH. However, high doses of Paracetamol cause an increase in NAPQI so that the detoxification process is ineffective and causes liver cell damage [54]. The results of this study showed that the AST concentration in the group treated with the addition of propolis liposomes was lower than the group treated with Paracetamol induction. Even the AST concentration in the group treated with the addition of propolis liposomes was still lower than the group treated with the addition of ordinary propolis. This showed that propolis in the form of liposomes is more effective as a hepatoprotective agent than ordinary propolis. Propolis in the form of liposomes is more easily absorbed by the tissue because it is nanoparticle size and has a bilayer structure that matches the structure of the cell membrane.

\section{EFFECT OF PROPOLIS ON BT LEVEL}

Research conducted by Mahani et al. [31] measured BT concentrations in three groups. Normal BT concentrations range from 0.3 to $1.2 \mathrm{mg} \%$. On the other hand, the $\mathrm{P} 1$ and $\mathrm{P} 2$ groups (the propolis supplementation group) experienced a decrease in BT, namely, 1.05 and $0.91 \mathrm{mg} \%$, respectively. This suggests that administration of propolis can prevent oxidative damage to the liver during the intensive treatment phase. At the advanced treatment stage, BT continued to decline in all groups. At week 24 the BT concentrations of the P0, P1, and P2 groups decreased, namely, by $0.81,0.88$, and $0.70 \mathrm{mg} \%$. The BT concentration in the P2 group was the lowest compared to other groups. This suggests that high doses of propolis supplementation are effective in protecting the liver from oxidative damage due to the hepatotoxic effects of ATD. From SGPT, SGOT, and BT values as a whole, it is clear that the P2 group did not show hepatotoxicity and on the other hand the P0 group showed hepatotoxicity.

These results were also substantiated by the work of of Nna et al. [55] with Malaysian propolis in Streptozotocin (STZ)-induced mice. According to Graham et al. [56] diabetes disease induced from STZ. STZ is a glucosamine-nitrosourea compound produced from Streptomyces achromogenes which is used clinically as chemotherapy in pancreatic $\beta$-cell carcinoma. Diabetes mellitus (DM) can cause oxidative stress in the liver by producing auto-oxidation of glucose and increasing levels of ROS $[57,58]$. DM is reported to reduce SOD, CAT, GPx, glutathioneS-transferase (GST), and glutathione reductase (GR) [59,60]. The results of this study indicated that BT levels significantly increase in diabetic control compared to normal control. This can be influenced by increased synthesis or the rate of excretion in the liver. In DC, there is an increase in LDH activity and causes the liver to excrete the remaining bilirubin resulting in the accumulation of bilirubin. The addition of propolis treatment can reduce BT levels in STZ-induced mice in addition of metformin. It can be concluded that the combination treatment of propolis and metformin can reduce the hepatotoxicity effect of the liver in DM patients.

This result is also supported by the research of Saleh [50] which states that aqueous extract of propolis can significantly reduce BT levels in liver cells induced by 4-tertiary-octylphenol (4-tert-OP) significantly. BT levels in mice given 4-tert-OP induction showed a significant increase when compared to controls, while mice given propolis extract had lower BT levels than controls. High BT levels on induction of 4-tert-OP indicate liver damage. According to El-Kott \& Owayss [61] an increase in BT indicates widespread damage to liver cells. The treatment of propolis extract was able to reduce BT levels, so it can be concluded that propolis is hepatoprotective and can reduce the toxic effects of 4-tert$\mathrm{OP}$ on the liver.

\section{EFFECT OF PROPOLIS ON GSH LEVEL}

Mahani et al. [31] also measured GSH concentrations in three groups. The results showed that at the GSH concentration at the $8^{\text {th }}$ week (the end of the intensive treatment stage), only the P2 group showed a GSH concentration of more than 1 , which was $1008 \mathrm{ug} / \mathrm{ml}$. The GSH concentrations of groups P0 and P1 were 0.93 and $0.94 \mathrm{ug} / \mathrm{ml}$, respectively. The highest GSH concentration was found in the P2 group during the intensive treatment stage (week 1-8). On the other hand, the GSH concentration at the same time in the $\mathrm{P} 0$ and $\mathrm{P} 1$ groups was lower than the P2 group. The difference in GSH concentration indicates that the addition of high doses of propolis ( $30 \%$ concentration) can help reduce radical metabolites so that excessive GSH depletion can be avoided. It can be concluded that high doses of propolis supplementation can create a better GSH status than the other groups, especially in the intensive treatment stage and can protect the liver from the toxic effects of ATD. Similar results were described by Banudevi et al. (2005), Chowdhury et al. (2006), and Palanisamy et al. (2011) High GSH concentrations are an indication of hepatoprotectivity. About $30 \%$ propolis supplementation can protect the liver from the hepatotoxic effects of ATD and create good liver antioxidant enzyme status during the intensive treatment phase. 
Nna et al. (2018) demonstrated same result with Malaysian propolis in STZ-induced mice. Chronic diabetes can cause major tissue damage to the liver by increasing oxidative stress $[65,66]$, inflammation $[57,66,67]$, and apoptosis [66,67]. In addition, DM can reduce levels of GPx, GST, and GR $[59,60]$. The results of this study indicated that GSH levels in Groups I, II, and III increased when compared to DC. The highest GSH levels were found in Group III. It can be concluded that the treatment of propolis and metformin is most effective in increasing the antioxidant status of the liver.

Similar results were also shown in the study of Chaa et al. [68]. In this study, epirubicin as an antibiotic increased biomarker compounds of oxidative stress in the liver (lipid peroxidation) and decreased endogenous antioxidant agents such as GSH, catalase, and SOD activity. Propolis from Tigzirt managed to restore this oxidative stress in liver tissue. This antioxidant effect is due to the presence of phenolic acids and flavonoids in propolis, as well as its ability to scavenge free radicals. The group of rats that were given propolis supplementation $250 \mathrm{mg} / \mathrm{kg}$ for 19 days showed a significant increase (86.51 U/g) compared to the control $(76.08 \mathrm{U} / \mathrm{g})$. The group of rats that were only given epirubicin showed a significant decrease in GSH levels $(12.78 \mathrm{U} / \mathrm{g})$ compared to the control group. This shows that the ethyl acetate propolis extract is able to restore the antioxidant status of the epirubicin-induced liver.

\section{EFFECT OF PROPOLIS ON SOD LEVEL}

Based on research conducted by Mahani et al. [31], the P2 group shows the highest SOD concentration in the $8^{\text {th }}$ week (end of the intensive treatment stage) with a concentration of $0.372 \mathrm{U} / \mathrm{ml}$ plasma. While the P0 and P1 groups had only 0.318 and $0.256 \mathrm{U} / \mathrm{ml}$ plasma concentrations, respectively. At week 24 (end of intervention), P2 group had increased SOD to $0.708 \mathrm{U} / \mathrm{ml}$ plasma. Meanwhile, the SOD concentrations of the P0 and P1 groups were only 0.526 and $0.461 \mathrm{U} /$ $\mathrm{ml}$ of plasma. This shows that the presence of high doses of propolis can create a better antioxidant enzyme status than the other groups and is a strong indication of hepatoprotectivity. This result is in line with Ramappa and Aithal [51] and Tostmann et al. [3] which stated that SOD restoration is an indication of hepatoprotectivity.

This result is also similar with the research done by Nna et al. [55] The results of this study indicate that the levels of SOD in Groups I, II, and III have increased when compared to DC. The highest SOD levels were found in Group III. It can be concluded that the treatment of propolis and metformin is most effective in increasing the antioxidant status of the liver. Propolis is able to improve the antioxidant status of the liver directly, indirectly, or both. Directly, propolis can directly trap ROS in the liver. Indirectly, propolis can increase the antioxidant status of the liver by reducing levels of fasting blood glucose so that it will limit the formation of ROS. An increase in antioxidant enzymes in diabetes models with the addition of propolis treatment was also found in studies using propolis from Taiwan [69], Egypt [70], China [71,72], and Brazil [72].

\section{EFFECT OF PROPOLIS ON NUTRITIONAL STATUS}

Based on the literature studies, the effects of propolis for TB sufferers include the ability to fight M.tbc infection and synergize with OAT so that it has the potential as an ingredient to accelerate the healing process for pulmonary tuberculosis sufferers. In addition, the ability of propolis as a hepatoprotector has the potential to protect the hepatotoxic effects of OAT which, in turn, is useful for accelerating the recovery process of the nutritional status of patients with pulmonary tuberculosis. Restoration of nutritional status of patients with pulmonary tuberculosis can be measured by knowing changes in BW and body mass index (BMI) [31].

One of the nutritional statuses that are measured to determine the effect of propolis is BW. Based on a study conducted by Mahani et al. [31], the OAT induction group without propolis supplementation experienced a decrease in BW until the $4^{\text {th }}$ week. This reduction in BW is strongly thought to be due to the hepatotoxic effect of OAT, namely nausea, dizziness, and decreased appetite, so that the intake of nutrients is lower than normal. When compared with other groups, the OAT induction group with propolis supplementation did not experience a decrease in BW and immediately increased since the beginning of the intervention. This increase in BW is thought to be due to the fact that $30 \%$ propolis supplementation was effective in reducing the hepatotoxic effect of standard doses of OAT. The results of this study indicate a strong indication that the intensive use of OAT has an effect on reducing BW through the hepatotoxic mechanism.

Intensive administration of OAT can reduce a person's nutritional status as a result of the hepatotoxic effect. In contrast, supplementation of 20 drops of propolis with a concentration of $30 \%$ on OAT can reduce the effects of decreasing nutritional status due to OAT consumption. Even being able to improve the nutritional status of the subject is better than the base line. This shows a strong indication that propolis supplementation with a concentration of $30 \%$ in OAT every day can accelerate the recovery of the subject's nutritional status. The recovery of BW and BMI is faster and greater as shown by the highdose propolis group which is able to reduce nausea since the beginning of the intervention. In addition, the recovery of their weight and body mass is also an indication that their nutrients are no longer used to fight infection as a result of their recovery in the $5^{\text {th }}$ week. The effect is, after the $5^{\text {th }}$ week these nutritional resources are used to restore their nutritional status.

This is confirmed by the research of Chaa et al. [68]. A very significant weight loss occurred in mice that received only epirubicin (G1) injections. G4 mice (rats given $250 \mathrm{mg} / \mathrm{kg}$ EAP) experienced significant weight gain up to the $19^{\text {th }}$ day of supplementation. Mice in G1 (control) and G4 did not show any behavioral changes indicating that propolis extract could inhibit epirubicin hepatotoxicity. Significant changes in physical activity and behavior occurred in mice on G2 (which only received epirubicin) such as: Drowsiness, hypoactivity, hair straightening, tachycardia, difficulty breathing, and loss of balance.

\section{IDENTIFICATION OF ACTIVE COMPOUNDS OF PROPOLIS AS ANTI HEPATOTOXICITY NUTRACEUTICAL}

Based on the literature studies, there are 11 active compounds that are strongly suspected of having an antihepatotoxicity/antioxidant role. These compoundsfallintotwocategories,namely,phytochemicalsandlipids. Active compounds classified as phytochemicals are: (1) 2,6-Dimethoxyphenol, (2) Methyl- $\alpha$-d-glucopyranoside, (3) 1,6-Anhydro-Beta-D-Glucopyranose, (4) (2S, 3R) -3-Allyl-3-methylapfelsaure-4-ethylester, (5) 5-Azulenemethanol, 1,2,3,3a, 4,5,6,7-octahydro-alpha, alpha, 3,8-tetramethyl, and (6) 1,4,5-Trimethylnaphthalene. Like antituberculosiscompounds, glycosides (methyl-alpha-D-glucopyranosideand 1,6-Anhydro-Beta-D-Glucopyranose) also act as the main hepatoprotector compound with a concentration of $40.57 \%$. While active compounds classified as lipids are: (1) Tridecanoic acid, (2) Tetra decanoic acid, (3) Pentadecanoic acid, and (4) Hexadecenoic acid. 2,6-dimethoxyphenol [73], 1,6-anhydro-beta-d-glucopyranose compounds [74], (2S, 3R) -3-Allyl3-methylapfelsaure-4 -ethylester [75,76], 1,4,5-trimethylnaphthalene showed reduction of 2,2-diphenyl-1-picrylhydrazyl (DPPH) radical compounds. They can work to reduce radical metabolites by binding to them. Likewise, methyl- $\alpha$-d-glucopyranoside and 5-azulenemethanol, 1,2,3,3a, 4,5,6,7-octahydro-alpha, alpha, and 3,8-tetramethyl compounds act as hepatoprotectors. They work by reducing radical metabolites. This is based on the results of research by Kokanova-Nedialkova et al. [77] and Vinholes et al. [78] which showed that the two compounds had a strong ability to reduce radical compounds (DPPH). Glycerol (propanetriol) is a lipid compound that acts as a hepatoprotector, but is not antioxidant. Glycerol has the ability to strengthen membranes and cell walls to deliver antibacterial agents [79]. This role is very important because it can protect the membranes and cell walls of the liver, which interact a lot with radical metabolites used to fight M.tbc. 


\section{CONCLUSION}

Supplementation of stingless bee propolis has been shown to act as a hepatoprotector and has a positive effect on patients with drug-induced DILI by reducing liver oxidative damage, which is characterized by decreased levels of SGPT, SGOT, and BT as well as increased levels of SOD and GSH. Supplementation of bee propolis without stingers has been proven to reduce liver infection so that the nutrients possessed can be used to restore the nutritional status of DILI patients, which is characterized by increased BMI and BB values at the end of the intervention.

\section{ACKNOWLEDGMENTS}

The authors express gratitude to the Faculty of Agric. Industrial Technology of Universitas Padjadjaran for facilitating the research.

\section{CONFLICT OF INTEREST}

The authors declare no conflict of interest associated with this study.

\section{REFERENCES}

1. Björnsson ES. Hepatotoxicity by drugs: The most common implicated agents. Int J Mol Sci 2016;17:224.

2. Nishimura Y, Kurata N, Sakurai E, Yasuhara H. Inhibitory effect of antituberculosis drugs on human cytochrome P450-mediated activities. J Pharmacol Sci 2004;96:293-300.

3. Tostmann A, Boeree MJ, Aarnoutse RE, De Lange WC, Van Der Ven AJ, Dekhuijzen R. Antituberculosis drug-induced hepatotoxicity: Concise up-to-date review. J Gastroenterol Hepatol 2008;23:192-202.

4. Wen X, Wang JS, Neuvonen PJ, Backman JT. Isoniazid is a mechanismbased inhibitor of cytochrome P 450 1A2, 2A6, 2C19 and 3A4 isoforms in human liver microsomes. Eur J Clin Pharmacol 2002;57:799-804.

5. Lewis JH, Stine JG. Nonsteroidal antiinflammatory drugs and leukotriene receptor antagonists. In: Drug-Induced Liver Disease. Amsterdam, Netherlands: Elsevier; 2013. p. 369-401.

6. Bonfanti P, Landonio S, Ricci E, Martinelli C, Fortuna P, Faggion I, et al. Risk factors for hepatotoxicity in patients treated with highly active antiretroviral therapy. JAIDS J Acquir Immune Defic Syndr 2001;27:316-8.

7. Jiménez-Alonso J, Osorio JM, Gutiérrez-Cabello $\mathrm{F}$, de la Osa AL, León L, García JD. Atorvastatin-induced cholestatic hepatitis in a young woman with systemic lupus erythematosus. Arch Intern Med 1999;159:1811-7.

8. Pelli N, Setti M, Ceppa P, Toncini C, Indiveri F. Autoimmune hepatitis revealed by atorvastatin. Eur J Gastroenterol Hepatol 2003;15:921-4.

9. Njoku D, Laster MJ, Gong DH, Eger EI, Reed GF, Martin JL. Biotransformation of halothane, enflurane, isoflurane, and desflurane to trifluoroacetylated liver proteins: Association between protein acylation and hepatic injury. Anesth Analg 1997;84:173-8.

10. Chalasani N, Fontana RJ, Bonkovsky HL, Watkins PB, Davern T, Serrano J, et al. Causes, clinical features, and outcomes from a prospective study of drug-induced liver injury in the United States. Gastroenterology 2008;135:1924-4.e4.

11. Girling DJ. The hepatic toxicity of antituberculosis regimens containing isoniazid, rifampicin and pyrazinamide. Tubercle 1977;59:13-32.

12. Devarbhavi H, Dierkhising R, Kremers WK, Sandeep MS, Karanth D, Adarsh CK. Single-center experience with drug-induced liver injury from India: Causes, outcome, prognosis, and predictors of mortality. Am J Gastroenterol 2010;105:2396-404.

13. World Health Organization. Global Tuberculosis Report 2013. Geneva: World Health Organization; 2013.

14. Khan R, Sultana S. Farnesol attenuates 1, 2-dimethylhydrazine induced oxidative stress, inflammation and apoptotic responses in the colon of Wistar rats. Chem Biol Interact 2011;192:193-200.

15. Bankova V, Popova M, Bogdanov S, Sabatini AG. Chemical composition of European propolis: Expected and unexpected results. Z Naturforschung C 2002;57:530-3.

16. Alencar SM, Oldoni TC, Castro ML, Cabral IS, Costa-Neto CM, Cury JA, et al. Chemical composition and biological activity of a new type of Brazilian propolis: Red propolis. J Ethnopharmacol 2007:113:278-83

17. Fernandes A Jr., Balestrin EC, Betoni JE, de Orsi RO, de Cunha ML, Montelli AC. Propolis: Anti-Staphylococcus aureus activity and synergism with antimicrobial drugs. Mem Inst Oswaldo Cruz
2005;100:563-6.

18. Amoros M, Lurton E, Boustie J, Girre L, Sauvager F, Cormier M. Comparison of the anti-herpes simplex virus activities of propolis and 3-methyl-but-2-enyl caffeate. J Nat Prod 1994;57:644-7.

19. Serkedjieva J, Manolova N, Bankova V. Anti-influenza virus effect of some propolis constituents and their analogues (esters of substituted cinnamic acids). J Nat Prod 1992;55:294-7.

20. Murad JM, Calvi SA, Soares A, Bankova V, Sforcin JM. Effects of propolis from Brazil and Bulgaria on fungicidal activity of macrophages against Paracoccidioides brasiliensis. J Ethnopharmacol 2002;79:331-4.

21. Tosi B, Donini A, Romagnoli C, Bruni A. Antimicrobial activity of some commercial extracts of propolis prepared with different solvents. Phytother Res 1996;10:335-6.

22. Ansorge S, Reinhold D, Lendeckel U. Propolis and some of its constituents down-regulate DNA synthesis and inflammatory cytokine production but induce TGF- $\beta 1$ production of human immune cells. Z Naturforschung C 2003;58:580-9.

23. De Castro SL, Higashi KO. Effect of different formulations of propolis on mice infected with Trypanosoma cruzi. J Ethnopharmacol $1995 ; 46: 55-8$

24. Bankova V. Recent trends and important developments in propolis research. Evid Based Complement Altern Med 2005;2:29-32.

25. Tsai FH, Lien JC, Lin LW, Chen HY, Ching H, Wu CR. Protective effect of Broussonetia papyrifera against hydrogen peroxide-induced oxidative stress in SH-SY5Y cells. Biosci Biotechnol Biochem 2009;73:1933-9.

26. Bhadauria M, Nirala SK, Shukla S. Duration-dependenthepatoprotective effects of propolis extract against carbon tetrachloride-induced acute liver damage in rats. Adv Ther 2007;24:1136-45.

27. Panjaitan RG. Pengujian Aktivitas Hepatoprotektor Akar Pasak Bumi (Eurycoma longifolia Jack.). Bogor: Disertasi Inst Pertan Bogor; 2008.

28. Halliwell B, Gutteridge JC. Lipid peroxidation, oxygen radicals, cell damage, and antioxidant therapy. Lancet Br Ed 1984;8391:1396-7.

29. Kumarappan C, Vijayakumar M, Thilagam E, Balamurugan M, Thiagarajan M, Senthil S, et al. Protective and curative effects of polyphenolic extracts from Ichnocarpus frutescense leaves on experimental hepatotoxicity by carbon tretrachloride and tamoxifen. Ann Hepatol 2016;10:63-72.

30. Mahdi C, Zukiaturrahmah A, Pratama DA, Nugraheni PW. Trigona sp. propolis ethanolic extract decreased chloramphenicol-induced serum glutamic oxaloacetic transaminase and alkaline phosphatase levels of rats (Rattus novergicus). Indones J Cancer Chemoprevention 2018;9:110-7.

31. Mahani M, Sulaeman A, Anwar F, Damanik MR, Hardinsyah H, Ploeger A. Efficacy of propolis supplementation to accelerate healing process and body weight recovery of pulmonary tuberculosis patients. J Gizi Dan Pangan 2018;13:1-10.

32. Abdelsameea A, Mahgoub L, Abdel Raouf S. Study of the possible hepatoprotective effect of propolis against the hepatotoxic effect of atorvastatin in albino rats. Zagazig Univ Med J 2013;19:1-9.

33. Clarke AT, Mills PR. Atorvastatin associated liver disease. Dig Liver Dis 2006;38:772-7.

34. Banskota AH, Tezuka Y, Adnyana IK, Midorikawa K, Matsushige K, Message D, et al. Cytotoxic, hepatoprotective and free radical scavenging effects of propolis from Brazil, Peru, the Netherlands and China. J Ethnopharmacol 2000;72:239-46.

35. Omar NA, Allithy AN, Baghdadi H, Zolaly M, Abdel-Haleem M, Helmy MM, et al. Hepatoprotective effects exerted by propolis against doxorubicin-induced rat liver toxicity: A biochemical and histopathological study. Am J Cancer Prev 2016;4:36-40.

36. Zhang ZH, Tang JH, Zhan ZL, Zhang XL, Wu HH, Hou YN. Cellular toxicity of isoniazid together with rifampicin and the metabolites of isoniazid on QSG-7701 hepatocytes. Asian Pac J Trop Med 2012;5:306-9.

37. Yew WW, Leung CC. Antituberculosis drugs and hepatotoxicity. Respirology 2006;11:699-707.

38. Ma Z, Lienhardt C, McIlleron H, Nunn AJ, Wang X. Global tuberculosis drug development pipeline: The need and the reality. Lancet 2010;375:2100-9

39. Sudarsanam TD, Tharyan P. Rifampicin compared to isoniazid for preventing active TB in HIV-negative people at risk of developing active TB: Implications for public health. Clin Epidemiol Glob Health 2014:2:28-36

40. Syaripuddin M, Yuniar Y, Sari ID. Studi monitoring efek samping obat antituberkulosis fdc kategori 1 di Provinsi Banten dan Provinsi Jawa Barat. Med Penelit Pengemb Kesehat 2014;24:20692. 
41. Bhadauria M, Nirala SK, Shukla S. Duration-dependent hepatoprotective effects of propolis extract against carbon tetrachloride-induced acute liver damage in rats. Adv Ther 2007;24:1136-45.

42. Hashmi N, Muhammad F, Javed I, Khan JA, Khan MZ, Khaliq T, et al. Nephroprotective effects of Ficus religiosa Linn (peepal plant) stem bark against isoniazid and rifampicin induced nephrotoxicity in albino rabbits. Pak Vet J 2013;33:330-4.

43. Cevik MU, Acar A, Tanriverdi H, Varol S, Arikanoglu A, Yucel Y, et al. Toxic effects of isoniazid and rifampicin on rat brain tissue: The preventive role of caffeic acid phenethyl ester. Int J Pharmacol 2012;8:555-60.

44. Tanvir EM, Hasan MA, Nayan SI, Islam T, Ahmed T, Hossen MS, et al. Ameliorative effects of ethanolic constituents of Bangladeshi propolis against tetracycline-induced hepatic and renal toxicity in rats. J Food Biochem 2019;43:e12958.

45. Hossen MS, Tanvir EM, Prince MB, Paul S, Saha M, Ali MY, et al. Protective mechanism of turmeric (Curcuma longa) on carbofuraninduced hematological and hepatic toxicities in a rat model. Pharm Biol 2017;55:1937-45.

46. Paul S, Islam M, Tanvir EM, Ahmed R, Das S, Rumpa NE, et al. Satkara (Citrus macroptera) fruit protects against acetaminopheninduced hepatorenal toxicity in rats. Evid Based Complement Alternat Med 2016;2016:9470954.

47. Ahmed R, Tanvir EM, Hossen M, Afroz R, Ahmmed I, Rumpa NE, et al. Antioxidant properties and cardioprotective mechanism of Malaysian propolis in rats. Evid Based Complement Alternat Med 2017;2017:5370545.

48. Paulino N, Barbosa AP, Paulino AS, Marcucci MC. Hepatoprotective effect of green propolis is related with antioxidant action in vivo and in vitro. Oxid Antioxid Med Sci 2014;3:43-50.

49. Tanvir EM, Hossen MS, Shapla UM, Mondal M, Afroz R, Mandal M, et al. Antioxidant, brine shrimp lethality and analgesic properties of propolis from Bangladesh. J Food Biochem 2018;42:e12596.

50. Saleh EM. Antioxidant effect of aqueous extract of propolis on hepatotoxicity induced by octylphenol in male rats. Acta Toxicol Argent 2012;20:68-81.

51. Ramappa V, Aithal GP. Hepatotoxicity related to anti-tuberculosis drugs: Mechanisms and management. J Clin Exp Hepatol 2013;3:37-49.

52. Saba AB, Ola-Davies O, Oyeyemi MO, Ajala O. The toxic effects of prolonged administration of chloramphenicol on the liver and kidney of rats. Afr J Biomed Res 2000;3:133-7

53. Ambardekar RV, Mahadik KR, Paradkar AR, Harsulkar AM. Enhancement of hepatoprotective efficacy of propolis by fabrication of liposomes, as a platform nano-formulation for multi-component natural medicine. Curr Drug Deliv 2012;9:477-86.

54. Wallace JL. Acetaminophen hepatotoxicity: NO to the rescue. Br J Pharmacol 2004;143:1-2

55. Nna VU, Bakar AB, Mohamed M. Malaysian propolis, metformin and their combination, exert hepatoprotective effect in streptozotocininduced diabetic rats. Life Sci 2018;211:40-50.

56. Graham ML, Janecek JL, Kittredge JA, Hering BJ, Schuurman HJ. The streptozotocin-induced diabetic nude mouse model: Differences between animals from different sources. Comp Med 2011;61:356-60.

57. Lin X, Zhang Z, Chen JM, Xu YY, Ye HR, Cui J, et al. Role of APN and TNF-alpha in Type 2 diabetes mellitus complicated by nonalcoholic fatty liver disease. Genet Mol Res 2015;14:2940-6.

58. Muruganathan U, Srinivasan S, Vinothkumar V. Antidiabetogenic efficiency of menthol, improves glucose homeostasis and attenuates pancreatic $\beta$-cell apoptosis in streptozotocin-nicotinamide induced experimental rats through ameliorating glucose metabolic enzymes. Biomed Pharmacother 2017:92:229-39.

59. Foster SR, Dilworth LL, Thompson RK, Alexander-Lindo RL, Omoruyi FO. Effects of combined inositol hexakisphosphate and inositol supplement on antioxidant activity and metabolic enzymes in the liver of streptozotocin-induced Type 2 diabetic rats. Chem Biol Interact 2017;275:108-15.

60. Palsamy P, Sivakumar S, Subramanian S. Resveratrol attenuates hyperglycemia-mediated oxidative stress, proinflammatory cytokines and protects hepatocytes ultrastructure in streptozotocinnicotinamide-induced experimental diabetic rats. Chem Biol Interact 2010;186:200-10.
61. El-Kott AF, Owayss AA. Protective effects of propolis against the amitraz hepatotoxicity in mice. J Pharmacol Toxicol 2008;35:402-8.

62. Banudevi S, Arunkumar A, Sharmila M, Senthilkumar J, Balasubramanian K, Srinivasan N, et al. Diallyl disulfide-induced modulation of a few phase I and II drug metabolizing enzymes on Aroclor 1254 toxicity in Rattus norvegicus liver and ventral prostate. J Clin Biochem Nutr 2005;36:59-65.

63. Chowdhury A, Santra A, Bhattacharjee K, Ghatak S, Saha DR, Dhali GK. Mitochondrial oxidative stress and permeability transition in isoniazid and rifampicin induced liver injury in mice. J Hepatol 2006;45:117-26.

64. Palanisamy GS, Kirk NM, Ackart DF, Shanley CA, Orme IM, Basaraba RJ. Evidence for oxidative stress and defective antioxidant response in guinea pigs with tuberculosis. PLoS One 2011;6:e26254.

65. Gezginci-Oktayoglu S, Basaraner H, Yanardag R, Bolkent S. The effects of combined treatment of antioxidants on the liver injury in STZ diabetic rats. Dig Dis Sci 2009;54:538-46.

66. Giribabu N, Karim K, Kilari EK, Kassim NM, Salleh N. Antiinflammatory, antiapoptotic and proproliferative effects of Vitis vinifera seed ethanolic extract in the liver of streptozotocinnicotinamide-induced Type 2 diabetes in male rats. Can J Diabetes 2018;42:138-49.

67. Haligur M, Topsakal S, Ozmen O. Early degenerative effects of diabetes mellitus on pancreas, liver, and kidney in rats: An immunohistochemical study. Exp Diabetes Res 2012;2012:120645.

68. Chaa S, Boufadi MY, Keddari S, Benchaib AH, Soubhye J, Van Antwerpen $\mathrm{P}$, et al. Chemical composition of propolis extract and its effects on epirubicin-induced hepatotoxicity in rats. Rev Bras Farmacogn 2019;29:294-300

69. Chen LH, Chien YW, Chang ML, Hou CC, Chan CH, Tang HW, et al. Taiwanese green propolis ethanol extract delays the progression of Type 2 diabetes mellitus in rats treated with streptozotocin/high-fat diet. Nutrients 2018;10:503

70. Rivera-Yañez N, Rodriguez-Canales M, Nieto-Yañez O, JimenezEstrada M, Ibarra-Barajas M, Canales-Martinez MM, et al. Hypoglycaemic and antioxidant effects of propolis of Chihuahua in a model of experimental diabetes. Evid Based Complement Alternat Med 2018;2018:4360356.

71. Fuliang HU, Hepburn HR, Xuan H, Chen M, Daya S, Radloff SE. Effects of propolis on blood glucose, blood lipid and free radicals in rats with diabetes mellitus. Pharmacol Res 2005;51:147-52.

72. Zhu W, Chen M, Shou Q, Li Y, Hu F. Biological activities of Chinese propolis and Brazilian propolis on streptozotocin-induced Type 1 diabetes mellitus in rats. Evid Based Complement Alternat Med 2011;2011:468529.

73. Adelakun OE, Kudanga T, Green IR, le Roes-Hill M, Burton SG. Enzymatic modification of 2, 6-dimethoxyphenol for the synthesis of dimers with high antioxidant capacity. Process Biochem 2012;47:1926-32.

74. Shaikh MH, Subhedar DD, Khan FA, Sangshetti JN, Shingate BB. 1, 2, 3-Triazole incorporated coumarin derivatives as potential antifungal and antioxidant agents. Chin Chem Lett 2016;27:295-301

75. Escribano J, Cabanes J, Jiménez-Atiénzar M, Ibañez-Tremolada M, Gómez-Pando LR, García-Carmona F, et al. Characterization of betalains, saponins and antioxidant power in differently colored quinoa (Chenopodium quinoa) varieties. Food Chem 2017;234:285-94.

76. Becerril-Chávez H, Colín-González AL, Villeda-Hernández J, GalvánArzate S, Chavarría A, de Lima ME, et al. Protective effects of S-allyl cysteine on behavioral, morphological and biochemical alterations in rats subjected to chronic restraint stress: Antioxidant and anxiolytic effects. J Funct Foods 2017:35:105-14.

77. Kokanova-Nedialkova Z, Nedialkov P, Kondeva-Burdina M, Simeonova R, Tzankova V, Aluani D. Chenopodium bonus-henricus L.-A source of hepatoprotective flavonoids. Fitoterapia 2017;118:13-20.

78. Vinholes J, Rudnitskaya A, Gonçalves P, Martel F, Coimbra MA, Rocha SM. Hepatoprotection of sesquiterpenoids: A quantitative structure-activity relationship (QSAR) approach. Food Chem 2014; 146:78-84

79. Ma Y, Xin L, Tan H, Fan M, Li J, Jia Y, et al. Chitosan membrane dressings toughened by glycerol to load antibacterial drugs for wound healing. Mater Sci Eng C Mater Biol Appl 2017;81:522-31. 